\title{
The influence of drought and thinning on leaf area index estimates from canopy transmittance method
}

\author{
A Cutini \\ Istituto Sperimentale per la Selvicoltura, Viale S Margherita 80, 52100 Arezzo, Italy
}

(Received 6 September 1994; accepted 15 December 1995)

\begin{abstract}
Summary - Leaf area index (LAl) estimates from litterfall and from canopy transmittance measurements in photosynthetically active radiation (PAR) and total solar irradiance wave bands were compared in Turkey oak (Quercus cerris $L$ ) stands. The aim was to evaluate advantages and limits of the transmittance measurements method in estimating $L A I$ and to determine whether the modifications due to silvicultural operations and to different climatic conditions affected the accuracy of this method. Data were collected in thinned and unthinned experimental plots established at two different locations: Valsavignone, in the Apennines, with a wet climate ("wet site"), and Caselli, near the Thyrrenian coast, with a longer and more severe summer dry period ("dry site"). Differences in stand density and LAI due to silvicultural operations led to significant differences in transmittance but did not affect light extinction coefficient $(k)$. On the contrary, environmental constraints influenced canopy properties as transmittance and $k$. However, the variability in canopy properties do no limit the capability of canopy transmittance, measured in the PAR wave band, to be a good predictor (error $< \pm 5 \%$ ) of LAl at stand level. Some considerations are made about $k$ and its value in PAR and total solar irradiance wave bands, and on variability in canopy structure of a given species in relation to drought.
\end{abstract}

canopy properties / leaf area index / light extinction coefficient / drought / Quercus cerris

Résumé - Influence de la sécheresse et des éclaircies sur la détermination de l'indice foliaire par la mesure de la transmittance. On analyse l'indice foliaire (LAl), la transmittance - dans la bande de la PAR et du rayonnement global - et le coefficient d'extinction de la lumière $(\mathrm{k})$ pour évaluer l'influence de la sécheresse et des éclaircies sur le soin la méthode d'évaluation du LAl par la mesure de la transmittance et sur les caractéristiques du couvert dans des peuplements de chêne chevelu (Quercus cerris $L$ ). L'étude a concerné deux séries de parcelles permanentes éclaircies ou non: la première placée dans l'Apennin central (Valsavignone) avec un été modérément sec, la deuxième près de la cöte tyrrhénienne (Caselli), caractérisée par une sécheresse estivale plus marquée. Les différences de densité et du LAl, causées par le traitement sylvicole, ont influencé de façon significative la transmittance au-dessous de la cime mais non la valeur du k. Au contraire, les différences climatiques ont modifié les caractéristiques des feuilles et la valeur du $\mathrm{k}$, spécifiquement calculé pour le chêne chevelu. La variabilité des caractéristiques du couvert des peuplements toutefois n'a pas affecté la précision 
(erreur $< \pm 5 \%$ ) de l'évaluation du LAl par la mesure de la transmittance dans la bande de la PAR. On discute sur les adaptations des cimes pour réduire les effets de la sécheresse et sur linfluence des telles modifications sur les valeurs de $\mathrm{k}$.

caractéristiques de couvert / indice foliaire / coefficient d'extinction / sécheresse / Quercus cerris

\section{INTRODUCTION}

Leaf area index (LAI), vertical distribution of the foliage, leaf inclination angles, leaf properties and clumpiness of foliage are the main variables influencing structural canopy properties and, together with phenology, they regulate all the main ecological and ecophysiological processes in a forest stand. LAl especially influences not only the structure and the development of the stand (growth of the understory, natural regeneration, etc) but also light and rain interception, vertical variation of temperature, evapotranspiration and photosynthesis; consequently, it is related to stand productivity (Gholz, 1982; Waring, 1983).

Despite its importance, however, direct measurement of LAl is nearly impossible in forest stands and indirect procedures are more commonly used. Indirect estimates based on tree allometry and litterfall are labor-intensive and do not always produce accurate and unbiased LAl estimates (Burton et al, 1991). Recently, starting from the assumption that the total amount of radiation intercepted by the canopy layer of a stand depends on the incident irradiance, the canopy structure and the foliage properties, Marshall and Waring (1986) proposed an alternative method of estimating LAI in forest stands. The method is based on the exponential decay of light intensity due to canopy light interception, described by fitting a light extinction coefficient to the BeerLambert law (Monsi and Saeki, 1953; Kasanga and Monsi, 1954; Saeki, 1960):

$$
I=10 e^{-k L A I / \cos \theta}
$$

where $l$ is incident radiation beneath the canopy, 10 is incident radiation above the canopy, $e$ is the base of natural logarithms, $k$ is the light extinction coefficient, LAI is stand leaf area index and $\theta$ the solar zenith angle. This method was used successfully to estimate LAl of different coniferous (Pierce and Running, 1988; Smith et al, 1991) and broad-leaf (Cannell et al, 1987; Burton et al, 1991) stands. Furthermore, the difficulties of measuring mean light intensities inside the canopy, due to the typical heterogeneity of light distribution in the forest stands, were recently reduced with the development of hand-held, battery-powered light sensors which allow a rapid and accurate estimation of light intensity within forest stands.

Nevertheless, some questions have arisen about this method and the light extinction coefficient. Recently, some authors (Burton et al, 1991; Smith et al, 1991; Smith, 1993; Martens et al, 1993), with reference to differences in stand density and in canopy architecture, pointed out the limits of the use of species' average light extinction coefficient for estimating LAI. Furthermore, canopy properties depend on environmental constraints. In fact, drought avoidance in forest trees involves not only the capability to maintain an adequate water absorption and a good water status in transpiring organs but the reduction of energy load and foliar water losses (Hinckley et al, 1981). Thus, each tree or stand regulates its characteristics as well as canopy properties (architecture and leaf characteristics) in order to maximize the advantages of a high light absorption and to limit the consequences of water shortage, high temperature and irradiance. The utmost importance 
of these adaptations concerns especially those regions where these environmental constraints are severe for a long time during the year, such as the Mediterranean region.

These aspects led us to question whether variability in canopy structure and architecture between stands of a given species can influence light extinction property of the crown. Therefore, we compared LAl estimates from litterfall and from canopy transmittance methods, which consider photosynthetically active radiation (PAR) and total solar irradiance ( $\mathrm{g}$ ) wave bands, in Turkey oak (Quercus cerris $L$ ) stands both under different silvicultural treatments and climatic conditions. As a consequence, it was possible to evaluate advantages and limits of the use of this method in estimating LAl and to determine whether the modifications due to silvicultural operations and to different climatic conditions affected the accuracy of the methods based on light transmittance measurements.

\section{MATERIALS AND METHODS}

Turkey oak is the main oak species in Italy. It is largely spread, especially in the peninsula, and grows from sea level up to the mountain belt of the Apennines, showing a good adaptability to different environmental conditions. The study was carried out in two Turkey oak forests in Tuscany (central Italy); the first (near Valsavignone $43^{\circ} 43^{\prime} \mathrm{N}, 12^{\circ} 02^{\prime} \mathrm{E}$ ) is located in the central Apennines and grows in a "wet site". The second (Caselli, $43^{\circ} 14^{\prime} \mathrm{N}, 10^{\circ} 42^{\prime} \mathrm{E}$ ) is near the Thyrrhenian coast, in a "dry site". Consequently, the latter showed a lower mean annual rainfall, a higher mean temperature and was characterized by a longer and more severe summer dry period. The annual water deficit, calculated according to the method proposed by Thornthwaite and Mather (1957), was more than twice the one of the wet site (table I). The stands concerned were man. aged as simple coppices with standards for a long time and growing on deep acid brown soils with a good nutrient availability (Guidi, 1976; Amorini and Fabbio, 1988).

The research was carried out on two 5000 $\mathrm{m}^{2}$ plots in the wet site and on four $900 \mathrm{~m}^{2}$ plots in the dry site. The plots are part of a permanent thinning trial established at the beginning of the 1970 s by the Istituto Sperimentale per la Selvicoltura in order to compare different management options for the conversion of Turkey oak coppice into high forest. The natural evolution of aging coppice (control, no silvicultural operation applied) was compared with the conversion into high forest by thinnings of different intensity. A first selective thinning was carried out in 1972 in the wet site (Amorini and Fabbio, 1988) and in 1970 in the dry site (Guidi, 1976); a second thinning was carried out, respectively, in 1984 and in 1989.

At each site, data were collected in the control and in the heavy thinned plots in which the number of stems in the upper crown canopy was quite the same (about 700-1 000 per ha). In the dry site, data from each thesis (two plots) were pooled and averaged out.

Since 1991, nine $0.25 \mathrm{~m}^{2}$ litterfall traps, randomly distributed in each plot, were used to estimate LAI. Litterfall was collected periodically

Table I. Site characteristics and type of climate according to Thornthwaite (1948) classification.

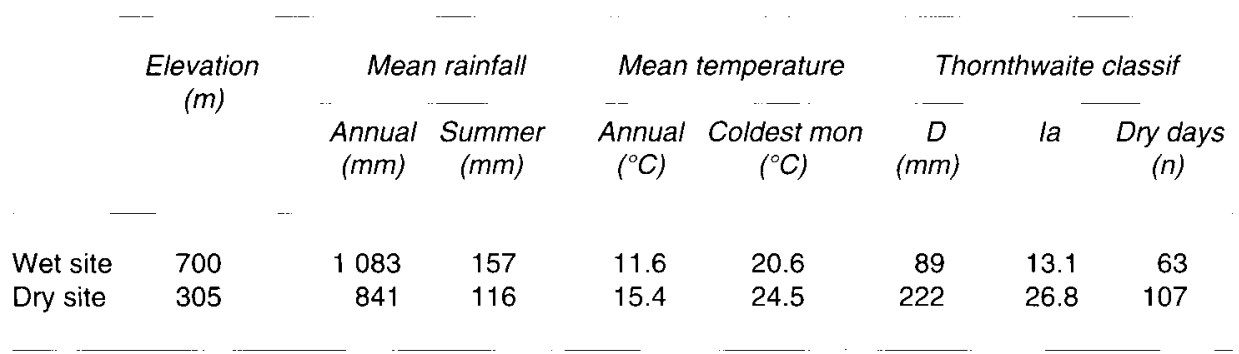

D: annual water deficit; la: drought index. 
(every 15 days in autumn and once a month during the other seasons), sorted into components (leaves, branches, fruits) and then dried to constant weight. LAl (one-sided projected area) was estimated using the specific leaf area (SLA, leaf area for $1 \mathrm{~g}$ of leaf dry weight). SLA and other morphometric variables (average dry weight and leaf area) were determined on a subsample represented by the leaves of one trap, systematically chosen on each plot, at every collection, for a total of 3010 leaves at Valsavignone and 1639 leaves at Caselli. The area of every unwrinkled and undamaged leaf was measured with a Delta$T$ area meter (Delta-T, Burwell, UK) and its dry weight measured after oven-drying. This procedure was suitable in relation to the characteristics of Turkey oak leaf, quite thick and leathery. Therefore, only a small part of the harvested leaves was rejected because wrinkled. In order to avoid an inaccurate estimate of standing $L A I$ because of the use of leaves collected from littertraps and partially shrinked, the obtained LAI value was corrected by the coefficient of shrinkage (Vanseveren, 1969), estimated on a green leaf sample collected directly from several trees. All data were analyzed for each site and silvicultural treatment using one-way ANOVA.

A Sunfleck Ceptometer SF 80 (Decagon Devices Inc, Pulman, WA, USA) and a tube solarimeter (Delta-T-Devices Ltd, Burwell, UK) were used by two operators at the same time to measure PAR $(0.4-0.7 \mathrm{~mm})$ and global solar irradiance $(0.3-3.0 \mathrm{~mm})$. The ceptometer is a handheld linear quantum sensor with 80 light sensors placed at $1-\mathrm{cm}$ intervals along the probe measuring PAR. Sampling points were over the littertraps at $1.30 \mathrm{~m}$ height, avoiding the influence of shrubs and understory. Four instantaneous PAR measurements were taken, holding the ceptometer horizontally, at cardinal directions, averaged and stored in the instruments. Using this technique, at each stop the PAR value was the average of 320 measurement points. All readings were collected on sunny days near noon local solar time. A total of ten sets of light measurements under the canopy (I) were collected in each plot during June and July 1992 in the same sky condition and with a solar zenith angle $<25^{\circ}$, in order to ignore $\cos \theta$ in equation [1] and to reduce the influence of solar altitudes (Campbell and Norman, 1989). Concerning this, Campbell (1986) showed that the influence of solar zenith angle is negligible for angles smaller than $30^{\circ}$ in randomly oriented leaves of a wide variety of shapes. Measurements were also collected in an open area fully exposed to sunlight, before and after sampling each plot, in order to provide an estimate of total incoming PAR above the canopy $(10)$.

The tube solarimeter measures irradiance in the wave bands $0.35-2.5 \mathrm{~mm}$, effectively the same for the global solar irradiance. Sampling points and procedures were the same used with the ceptometer. At each stop only one measurement, holding the instrument horizontally and in a north to south direction, was taken because a tube solarimeter needs, for a good response, a 3 min exposure.

Equation [1] was used to estimate LAl by using the average canopy transmittance and the $k$ average value for broad-leaves $(0.65)$ proposed by Jarvis and Leverenz (1983). Furthermore, LAI estimates from litterfall were used in the same equation in order to determine the Turkey oak $k$ average value.

For each plot and set of measurements, the transmittance values and extinction coefficients, for both PAR (Tpar) and global solar irradiance $(T g)$, were averaged and analyzed by Student's $t$ test for paired observations, while data of the two locations were analyzed by one-way ANOVA and treatments were compared by the Tukey honestly significant difference (HSD) test.

\section{RESULTS}

The applied silvicultural treatment affected the main stand characteristics and led to a marked reduction $(50-60 \%$ of the basal area of the unthinned plots) of stocking (table II). The differences were slighter in the wet site as a consequence of the longer period since the last thinning. On the contrary, the differences in LAI values were higher in the wet site than in the dry site: in the former, the LAl in the thinned stand was $63 \%$ of the unthinned one, while, in the latter, it was $83 \%$.

Differences also occurred in the intersite comparison: the unthinned plots, notwithstanding a similarity in age, composition, structure and absence of disturbance, showed differences especially in basal area and $L A I$ values (table II). Although the higher 
Table II. Stand characteristics.

\begin{tabular}{lcccccc} 
& $\begin{array}{c}\text { Age } \\
\text { (years) }\end{array}$ & $\begin{array}{c}\text { Stems } \\
\left(n h a^{-1}\right)\end{array}$ & $\begin{array}{c}\text { Basal area } \\
\left(m^{2} h a^{-1}\right)\end{array}$ & $\begin{array}{c}\text { Dom height } \\
(\mathrm{m})\end{array}$ & $\begin{array}{c}\text { Litterfall } \\
\left(\mathrm{kg} \mathrm{ha}^{-1} y^{-1}\right)\end{array}$ & $\begin{array}{c}\text { LAl } \\
\left(\mathrm{m}^{2} \mathrm{~m}^{-2}\right)\end{array}$ \\
$\begin{array}{l}\text { Wet site } \\
\text { Thinned }\end{array}$ & 39 & 1004 & 20.69 & 19.96 & 4002 & 4.7 \\
Control & 39 & 4052 & 33.27 & 21.65 & 5800 & 7.4 \\
$\begin{array}{l}\text { Dry site } \\
\text { Thinned }\end{array}$ & 40 & 715 & 21.49 & & & \\
Control & 40 & 3589 & 41.30 & 21.90 & 4263 & 4.3 \\
\hline
\end{tabular}

LAl: leaf area index.

stocking in the dry site, both in control and thinned plots, the stand LAl values were higher in the wet site. The differences were smaller in thinned than in unthinned plots: LAl values in the dry site, in percentage of the one in the wet site, were 91.5 and $70.3 \%$ respectively, for thinned and unthinned plots.

The number of leaves in the unthinned plots was 4000 and $3662 \mathrm{~m}^{-2}$, respectively, for the wet and the dry site, while in the thinned plots the number was 2901 and $2886 \mathrm{~m}^{-2}$, respectively. The differences in leaf characteristics between control and thinned plots did not have significant results so that data were pooled together for the intersite comparison. At this level, the wet site showed a higher average dry weight, leaf area and SLA in comparison with the dry one, but only SLA had significantly different results (table III).

Assuming that the estimates of LAI from littertraps were accurate, LAl estimates, based on canopy transmittance and a $k$ average value of 0.65 , gave appreciable results (error $< \pm 5 \%$ ) using only the measurements in the PAR wave band; while using global solar irradiance, the underestimate increased up to $20-40 \%$ (table IV).

The Student's $t$-test highlighted the fact that canopy transmittance differences between control and thinned plots were significant both in PAR and in the global solar

Table III. Averages, standard deviations (in parentheses) and ANOVA of Turkey oak leaf characteristics.

$\begin{array}{lccc} & \begin{array}{c}\text { Dry weight } \\ (\mathrm{g})\end{array} & \begin{array}{c}\text { Leaf area } \\ \left(\mathrm{cm}^{2}\right)\end{array} & \begin{array}{c}S L A \\ \left(\mathrm{~cm}^{2} \mathrm{~g}^{-1}\right)\end{array} \\ & & & -152.3(5.8) \\ \text { Wet site } & 0.11(0.01) & 17.3(0.9) & 130.2(2.9) \\ \text { Dry site } & 0.12(0.01) & 14.9(0.8) & 13.78 \\ \text { Sig lev } & 0.14 & 2.98 & 0.00\end{array}$

SLA: specific leaf area. 
Table IV. Comparison between LAI estimates from litterfall and from canopy transmittance measurements.

\begin{tabular}{|c|c|c|c|c|c|}
\hline & \multirow{2}{*}{$\begin{array}{l}L A I \\
\text { traps }\end{array}$} & \multicolumn{2}{|c|}{ PAR } & \multicolumn{2}{|c|}{ Global solar radiation } \\
\hline & & $\begin{array}{c}L A I \\
\mathrm{k}=0.65 \\
b\end{array}$ & $\begin{array}{c}\text { Differ }(\%) \\
b-a\end{array}$ & $\begin{array}{c}L A t \\
\mathrm{k}=0.65 \\
c\end{array}$ & $\begin{array}{c}\text { Differ (\%) } \\
c-a\end{array}$ \\
\hline \multicolumn{6}{|l|}{ Wet site } \\
\hline Control & 7.4 & 7.1 & -4.3 & 4.6 & -37.7 \\
\hline Thinned & 4.7 & 4.6 & -1.9 & 3.5 & -24.6 \\
\hline \multicolumn{6}{|l|}{ Dry site } \\
\hline Control & 5.2 & 5.4 & 4.7 & 4.1 & -21.3 \\
\hline Thinned & 4.3 & 4.2 & -2.2 & 3.4 & -21.0 \\
\hline
\end{tabular}

PAR: photosynthetically active radiation; LAI: leaf area index.

irradiance wave bands (table $\mathrm{V}$ ). The low value of the coefficient of variation, in both the thinned and the unthinned stand, accounts for a random distribution of trees and of canopy elements.
Despite the marked differences in LAI, the $k$ values, calculated using litterfall LAI values, were similar in the control and in the thinned plots and no significant difference was found by the Student's $t$-test. The $k$ in

Table V. Statistics of transmittance and light extinction coefficient in the photosynthetically active radiation (PAR) and global solar irradiance $(\mathrm{g})$ wave bands.

\begin{tabular}{|c|c|c|c|c|c|c|c|c|c|c|c|}
\hline & \multicolumn{5}{|c|}{ Wet site } & \multicolumn{6}{|c|}{ Dry site } \\
\hline \multicolumn{3}{|c|}{ Transmittance (Tpar) } & \multicolumn{3}{|c|}{ kpar } & \multicolumn{3}{|c|}{ Transmittance (Tpar) } & \multicolumn{3}{|c|}{ kpar } \\
\hline Mean & $S D$ & CV \% & Mean & $S D$ & $\mathrm{CV} \%$ & Mean & $S D$ & $C V \%$ & Mean & $S D$ & $C V \%$ \\
\hline 0.01 & 0.001 & 10 & 0.65 & 0.08 & 12 & 0.03 & 0.005 & 17 & 0.68 & 0.11 & 16 \\
\hline 0.05 & 0.005 & 10 & 0.64 & 0.06 & 9 & 0.07 & 0.003 & 4 & 0.64 & 0.08 & 13 \\
\hline 11.5 & $\mathrm{~s}$ & & 0.2 & ns & & 2.7 & $\mathrm{~s}$ & & 2.0 & ns & \\
\hline \multicolumn{4}{|c|}{ Transmittance $(\mathrm{Tg})$} & $\mathrm{kg}$ & & \multicolumn{3}{|c|}{ Transmittance $(T g)$} & \multicolumn{2}{|c|}{$\mathrm{kg}$} & \\
\hline 0.05 & 0.01 & 22 & 0.41 & 0.04 & 10 & 0.07 & 0.02 & 29 & 0.50 & 0.04 & 8 \\
\hline 0.10 & 0.02 & 15 & 0.46 & 0.03 & 7 & 0.11 & 0.03 & 27 & 0.51 & 0.05 & 10 \\
\hline 9.4 & $\mathrm{~s}$ & & 2.1 & ns & & 6.2 & $s$ & & 0.8 & ns & \\
\hline
\end{tabular}

s: significant; ns: not significant. CV: coefficient of variation. 
the PAR wave band (kpar) and in the global solar irradiance wave band $(\mathrm{kg})$ were different (table VI). The ANOVA showed significant differences in $k$ value both in PAR and in global radiation wave band between the dry and the wet site (table IV), with the former having a higher $k$.

\section{DISCUSSION AND CONCLUSION}

The differences in stocking and LAl values between thinned and unthinned plots accounted for a substantial modification of stand characteristics due to the silvicultural treatment. If the aim of the applied thinning method was to cause a temporary interruption of canopy closure, the effects of thinning, 4-8 years later, were not restored as described by the lower values both in stocking and LAI.

Transmittance of thinned and unthinned plots was significantly different as a consequence of the reduction in stocking and LAl, but thinning did not affect canopy properties. In fact, despite the different levels of competition and development of the canopies between control and thinned plots and, especially, the different LAI values, thinning did not modify significantly either leaf characteristics or light extinction capacity of the crown (k). Small differences are probably the result of different LAI values between control and thinned plots in accordance with some authors who noted $k$ value changing as a consequence of different LAI (Cannell et al, 1987; Johansson, 1989; Smith et al, 1991). Another possible cause could be the amount of woody parts (stems, branches) and the different levels of influence on light interception. However, on the basis of the slight differences between thinned and unthinned plots in $k$ values, in comparison with the marked ones in stocking and LAI, it seems appropriate to assign to this aspect only a marginal role in change the light absorption pattern of a forest stand.

If stomatal closure is probably the most important means of drought avoidance at the plant level - such as other adaptations at whole canopy level, like leaf area reduction, higher leaf reflectance, leaf hairness, higher cuticle and leaf thickness, modifications of leaf inclination angles, premature leaf-fall contribute to reduce the energy load and the foliar water loss (Pereira, 1994). This is confirmed by results from the intersite comparison which pointed out a set of adaptations in canopy properties of Turkey oak. The stands growing in dry site, in order to limit the evapotranspiration, showed a marked reduction of LAl depending on quantitative and qualitative modifications. The stands had not only a smaller total leaf area (lower number of

Table VI. One way ANOVA and Tukey HSD test of the light extinction coefficient in the photosynthetically active radiation (PAR) and global solar irradiance (g) wave bands.

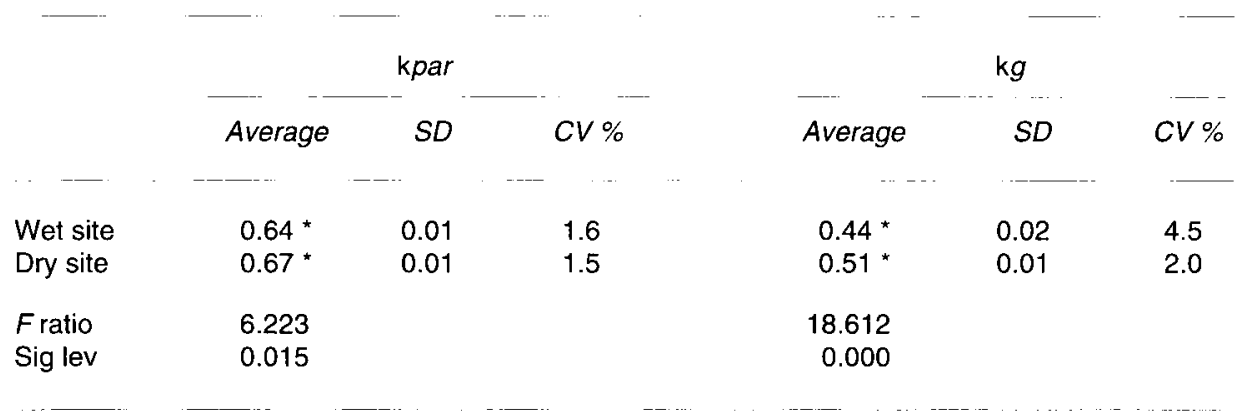

* Significantly different at $P<0.01$ at Turkey HSD test. CV: coefficient of variation. 
leaves and average leaf area), but thicker and more leathery leaves too. The slight differences in leaf area and SLA between control and thinned plots can be ascribed to the positive effect of thinning on tree water stress (Black et al, 1980; Aussenac and Granier, 1988), especially on dry sites. In confirmation of this, LAl differences between the wet and dry site were more pronounced in the unthinned stands than in the thinned plots.

The highlighted modifications in leaf and canopy properties influenced canopy light extinction capacity and justified the existence of significant differences in $k$ value between wet and dry site. At first, higher values of $k$ in the dry site could account for a larger light extinction capacity of the canopy. But this assertion is not in accordance with the need to reduce the negative influence of a high light absorption in a site with a severe and long dry period. Moreover, it would have been necessary to measure the stand reflectance to validate this hypothesis. Therefore, it is likely that the higher $k$ is due to a lower transmittance as a consequence not of a higher light absorption but of a higher reflectance, given the different leaf characteristics.

These observations allow a more detailed evaluation of the indirect methods based on light transmittance measurements in estimating LAl. Some authors pointed out the variability in canopy structure and architecture between stands of a given species and criticized the assumption of the constance of $k$ (Norman and Jarvis, 1974; Kellomaki et al, 1986; Smith et al, 1991; Martens et al, 1993). This is not in contrast with our results which noted a variability in canopy properties of Turkey oak stands due both to silvicultural treatment and climatic conditions even if the latter led to significant differences in $k$ values, while the former had a slight influence. In all the tested plots, however, the variability in canopy properties due to silvicultural treatment and, especially, to climatic conditions did not reduce the possibility to obtain appreciable estimates of LAI by using canopy transmittance measurements in the PAR wave band. The average kpar both in the wet (0.64) and the dry (0.67) sites, were higher than those observed $(0.473$ and 0.576 ) in a stand of Quercus rubra (Bolstad and Gower, 1990) and quite similar to the average value for broad-leaves of 0.65 ; this had negligible consequences on the accuracy of LAl estimates.

On the contrary, data from total solar irradiance underestimated markedly the LAI of the stands under examination. This result appears to be due to a much smaller leaf reflectance and transmittance in the PAR wave band than in the near-infrared one. Hence, a higher proportion of visible radiation is absorbed by leaves, resulting in higher extinction coefficients and, as we found here, in higher values of $\mathrm{Tg}$ than of $T$ par. As a consequence, the effective $k$ values in the two wave bands concerned: kpar was larger than $\mathrm{kg}$, in agreement with the results and observations reported by Johansson (1989) for Populus tremula and Betula pubescens and by Black et al (1991) for Douglas-fir.

On the basis of these results, it seems therefore inappropriate to define a specific average extinction coefficient tout court, but it is necessary to refer to the considered wave band. Furthermore, differences in canopy properties, which could affect $k$ values, depend mainly on climatic conditions. Silvicultural treatment, even though markedly modifying stand characteristics, does not change significantly $k$ values. However, the highlighted modifications in canopy properties do not limit the capacity of canopy transmittance, measured in the PAR wave band, to be a good predictor of LAI at stand level.

\section{ACKNOWLEDGMENTS}

I am particularly grateful to the technician $L$ Mencacci for manufacturing the littertraps and to $R$ del Barba and $\mathrm{M}$ Ceccarelli for helping with the 
field and laboratory work. I thank Prof G Scarascia Mugnozza of Univeristy of Tuscia (Viterbo, Italy) and one anonymous reviewer for the useful suggestions.

\section{REFERENCES}

Amorini E (1994) L'area sperimentale Valsavignone: evoluzione della struttura, della composizione specifica e della biometria in presenza ed assenza di trattamento. Ann Ist Sper Selv XXIII, 7-40

Amorini E, Fabbio G (1988) L'avviamento all'altofusto nei cedui a prevalenza di cerro. Risultati di una prova sperimentale a 15 anni dalla sua impostazione. Primo contributo. Ann Ist Sper Selv XVII, 5-101

Aussenac G, Granier A (1988) Effects of thinning on water stress and growth in Douglas-fir. Can $J$ For Res 18, 100-105

Black TA, Tan CS, Nnyamah JU (1980) Transpiration rate of Douglas fir trees in thinned and unthinned stands. Can Soil Sci 60, 625-631

Black TA, Chen JM, Lee X, Sagar RM (1991) Characteristics of shortwave and longwave irradiances under a Douglas-fir stand. Can J For Res 21, 1020-1028

Bolstad PV, Gower ST (1990) Estimation of leaf area index in 14 southern Wisconsin forest stands using a portable radiometer. Tree Physiol 7, 115-124

Burton AJ, Pregitzer KS, Reed DD (1991) Leaf area and foliar biomass relationships in Northern hardwood forests located along an $800 \mathrm{~km}$ acid deposition gradient. For Sci37, 1041-1059

Campbell GS (1986) Extinction coefficients for radiation in plant canopies calculated using an ellipsoidal inclination angle distribution. Agric For Meteorol 36, 317321

Campbell GS, Norman JM (1989) The description and measurement of plant canopy structure. In: Plant Canopies: Their Growth, Form and Function (G Russell, B Marshall, PG Jarvis, eds), Cambridge University Press, New York, 1-20

Cannell MGR, Milne R, Sheppard LJ, Unsworth MH (1987) Radiation interception and productivity of willow. J Appl Ecol 24, 261-278

Gholz HL (1982) Environmental limits on aboveground net primary production, leaf area and biomass in vegetation zones of the Pacific Northwest. Ecology $63,469-481$

Guidi G (1976) Primi risultati di una prova di conversione in un ceduo matricinato di cerro (Quercus cerris L). Ann ist Sper Selv VI, 253-278

Hinckley TM, Teskey RO, Duhme F, Richter H (1981) Temperate hardwood forests. In: Water Deficits and Plant Growth (TT Kozlowwsky, ed), Academic Press Inc, New York, 154-208
Jarvis PG, Leverenz JW (1983) Productivity of temperate, deciduous and evergreen forests. In: Physiological Plant Ecology, Enc of Plant Physiology (OL Lange et al, eds), Springer-Verlag, Berlin, 233-280

Johansson T (1989) Irradiance within the canopies of young trees of European aspen (Populus tremula) and European birch in stands of different spacing. For Ecol Manage 28, 217-236

Kasanga $\mathrm{H}$, Monsi $\mathrm{N}$ (1954) On the light transmission of leaves and its meaning for the production of matter in plant communities. Jpn J Bot 14, 304-324

Kellomaki S, Oker-Bloom P, Kuuluvainen T (1986) The effect of crown and canopy structure on light interception and distribution in a tree stand. In: Crop Physiology of Forest Trees (PMA Tigerstedt, P Puttonen, $V$ Koski, eds), Helsinky University Press, Helsinky, Finland, 107-116

Marshall JD, Waring $\mathrm{RH}$ (1986) Comparison of methods of estimating leaf-area index in old growth Douglas-fir. Ecology 67, 975-979

Martens SN, Ustin SL, Rousseau RA (1993) Estimation of tree canopy leaf area index by gap fraction analysis. For Ecol Manage 61, 91-108

Monsi M, Saeki T (1953) Uber den lichtfaktor in den Pflanzengesellschaften und seine Bedeutung fur die Stoffproduktion. Jpn Bot 14, 22-52

Norman JM, Jarvis PG (1974) Photosynthesis in Sitka spruce (Picea sitchensis [Bong] Carr). J App/ Ecol 11, 375-398

Pereira JS (1994) Physiological responses to drought in mediterranean oaks. In: Int Symp on Environmental Constraints and Oaks: Ecological and Physiological Aspects, Nancy, France, 29 Aug-1 Sept 1994

Pierce LL, Running SW (1988) Rapid estimation of coniferous forest leaf area index using a portable integrating radiometer. Ecology $69,1762-1767$

Saeki T (1960) Interrelationships between leaf amount, light distribution and total photosynthesis in a plant community. Bot Mag (Tokyo) 73, 55-63

Smith FW, Sampson DA, Long JN (1991) Comparison of leaf area index estimates from tree allometrics and measured light interception. For Sci 37, 1682-1688

Smith NJ (1993) Estimating leaf area index and light extinction coefficients in Douglas-fir (Pseudotsuga menziesii). Can J For Res 23, 317-321

Thornthwaite CW (1948) An approach toward a natural classification of climate. Geogr Rev 38, 55-94

Thornthwaite CW, Mather JR (1957) Instructions and tables for computing potential evapotranspiration and the water balance. Pubb/ Climatol 10, 1-311

Vanseveren JP (1969) Recherches sur l'écosystème forét. Série B : La chenaie mélangée calcicole de Virelles-Blaimont. Contribution 30 : L'index foliaire et sa mesure par photoplanimétrie. Bull Soc Roy Bot Belg 102, 373-385

Waring $\mathrm{RH}$ (1983) Estimating forest growth and efficiency in relation to canopy leaf area. $A d v$ Ecol Res $13,327-354$ 